\title{
MAKNA PERILAKU MINUM OBAT PADA PASIEN HIV/AIDS RAWAT JALAN DI VCT RSUP DR.KARIADI SEMARANG
}

\author{
Faradilla Sari, Endah Kumala Dewi, Y. F. La Kahija* \\ Fakultas Psikologi Universitas Diponegoro \\ J1. Prof Sudharto SH, Tembalang, Semarang 50275 \\ *franzlakahija@gmail.com
}

\begin{abstract}
For individuals with HIV/AIDS, making a decision to take a pill brings huge consequences. Taking medicine brings not only physical and psychological consequences, but also various social reactions, particularly those from family members and community. Individuals with HIV/AIDS also encountered social pressure and conflict with their environment. One might consider the pressure on the affected individuals as a challenge to continue their lives as well as resources to support them. The impact of taking medicines led individuals to give meaning to their behavior of pill taking. This qualitative study was conducted with phenomenological approach. Two women who were patients at Dr. Kariadi Hospital Semarang participated in this study. In collecting data, indepth interview and observation were used. The meaning of taking medicines for patients with HIV was obtained from the subjective experience of participants in coping with pain. The results showed that participants gave meaning to taking medicines as a life saving due to her wish to see her children achieve their dreams.
\end{abstract}

Keywords: meaning, taking medication, HIV/AIDS

\begin{abstract}
Abstrak
Bagi penderita HIV/AIDS, keputusan untuk minum obat merupakan keputusan besar dengan konsekuensi yang besar pula. Minum obat tidak hanya membawa konsekuensi fisik dan psikologis, tapi juga beragam reaksi sosial, terutama dari keluarga dan komunitas terdekat. Penderita HIV/AIDS juga mengalami tekanan sosial dan konflik dari lingkungan sosialnya. Tekanan yang diterima oleh penderita HIV/AIDS merupakan tantangan untuk melanjutkan hidup, sekaligus sebagai sumber dukungan bagi individu yang bersangkutan. Besarnya dampak dari pengalaman minum obat membuat individu memaknai perilaku minum obat bagi dirinya. Penelitian ini dilakukan dengan metode kualitatif dan menggunakan pendekatan fenomenologis. Partisipan sebanyak dua orang diperoleh melalui pencarian dengan kriteria-kriteria tertentu di VCT RSUP Dr. Kariadi Semarang. Metode pengumpulan data dilakukan dengan wawancara mendalam dan observasi. Makna minum obat diperoleh dari hasil pengalaman subyektif penderita HIV/AIDS dalam menghadapi penderitaan. Hasil penelitian ini menunjukkan bahwa penderita HIV/AIDS memaknai minum obat sebagai penyambung nyawa karena adanya harapan untuk mendampingi dan mewujudkan cita-cita anaknya.
\end{abstract}

Kata kunci: perilaku minum obat, HIV/AIDS

\section{PENDAHULUAN}

Kasus AIDS (acquired immune deficiency syndrome) di Indonesia menunjukkan peningkatan yang tajam. Istilah lain yang kerap dipertukarkan dengan AIDS adalah HIV (Human Immunodeficiency Virus). Data statistik dari Direktorat Jenderal Pemberantasan Penyakit Menular dan Penyehatan Lingkungan Hidup (Dirjen
PPM\&PL) Departemen Kesehatan RI menyebutkan bahwa sampai akhir maret 2009 sebanyak 6.668 orang mengidap HIV dan 16.964 orang menderita AIDS. Dari jumlah kasus di atas, 3.492 orang atau $20,58 \%$ penderita AIDS dinyatakan telah meninggal dunia.

AIDS merupakan kumpulan penyakit yang disebabkan oleh virus yang dinamakan 
Human Immunodeficiency Virus (HIV) (Kaplan, 1999) . Virus tersebut menginfeksi sistem kekebalan tubuh manusia dan sistem saraf (Seligson, 1992). HIV/AIDS merupakan salah satu penyakit yang masuk dalam kriteria penyakit kronis. Penyakit kronis merupakan penyakit yang dapat dikontrol perkembangannya, namun tidak dapat disembuhkan, sehingga semua kegiatan pemulihan dapat dilakukan seumur hidup yang membawa dampak besar dalam kehidupan manusia (Sanderson, 2004).

Salah satu akibat dari infeksi HIV adalah kerusakan pada sistem kekebalan tubuh kita. HIV membunuh satu jenis sel darah putih yang disebut sel CD4. Sel ini adalah bagian penting dari sistem kekebalan tubuh. Jika jumlah sel ini berkurang, sistem tersebut menjadi terlalu lemah untuk melawan infeksi. Jumlah sel CD4 dapat dihitung melalui tes darah khusus. Agar sistem kekebalan tubuh tetap sehat, perkembangan penyakit dari HIV menjadi AIDS dapat ditahan dengan memakai obat antiretroviral/ARV. ARV bekerja memperlambat reproduksi HIV dan memperpanjang kualitas hidup, dan mencegah terjadinya penyakit otak, bukan untuk mengobati penyakit. Terapi Antiretroviral (ART) menggunakan kombinasi dari beberapa obat. ART hanya berhasil jika dipakai secara patuh, sesuai dengan jadwal yaitu dua kali sehari pada waktu pagi dan malam. Apabila dosis terlupa, keefektifan terapi akan cepat hilang. Beberapa individu akan mengalami efek samping ketika memakai ART, terutama pada minggu-minggu pertama penggunaannya sehingga pengguna ART perlu diawasi oleh dokter yang berpengalaman dengan terapi ini ("Apa terapi antiretroviral itu?," 2009).

Dalam Pedoman Nasional Perawatan, Dukungan, dan Pengobatan bagi ODHA (2003) dijelaskan bahwa walaupun ART sudah menjadi kunci dalam penatalaksanaan penyakit HIV, ART memiliki beberapa keterbatasan yaitu: pertama, ART tidak mampu memberantas virus. Terapi ini gagal mengendalikan virus dalam kurang lebih sepertiga pasien pada uji klinis. Virus cepat meningkat kembali setelah berhenti terapi, atau menghentikan salah satu obat dalam kombinasi. Penderita harus melanjutkan terapi seumur hidup agar memperoleh manfaat yang optimal. Keterbatasan ART yang kedua adalah jenis HIV yang resisten sering muncul, terutama jika kepatuhan penderita pada terapi tidak sempurna. Kegagalan lebih mungkin terjadi pada tahap penyakit yang sudah lanjut. Ketiga, penularan HIV melalui perilaku yang berisiko dapat terus terjadi, walaupun viral load tidak terdeteksi. Keempat, Efek samping ART sering terjadi mulai dari yang ringan termasuk anemia, neutropenia, mual, sakit kepala, hepatitis akut, reaksi hipersensitif dan sindrom Stevens Johnson.

Efek samping yang ditimbulkan obat ARV ini dapat menurunkan kondisi kesehatan (Nursalam, 2007). Kasus inilah yang terkadang membuat penderita HIV/AIDS tidak mudah untuk membuat keputusan untuk mau minum obat dan menjalani berbagai pengobatan karena membawa dampak yang besar bagi penderitanya. Meski demikian pada individu-individu tertentu, krisis dan situasi ini justru dapat berfungsi sebagai pendorong untuk terus bertahan hidup menyelesaikan tugas perkembangannya sehingga mau minum obat agar kualitas hidupnya meningkat, walaupun dihadapkan dengan masalah yang berkaitan dengan peran, efek samping obat, kondisi fisik, psikologis, sosial, dan spiritual. Minum obat merupakan upaya yang dilakukan penderita sebagai perilaku peran sakit yang bertujuan untuk menjadi sehat dan memperpanjang hidup penderita.

Hasil wawancara awal dengan penderita HIV/AIDS (ODHA) rawat jalan di poliklinik penyakit dalam RSUP Dr. 
Kariadi Semarang terungkap bahwa meskipun mengetahui HIV/AIDS merupakan penyakit kronis yang tidak bisa disembuhkan, pasien tetap bertahan mau minum obat walaupun beberapa ODHA mengalami efek samping yang menyakitkan yang membawa ke penderitaan seperti pusing, mual, atau bintik merah. Selain efek samping itu, masalah yang sering dihadapi ODHA dalam perilaku minum obat adalah alergi yang tidak jarang membuat mereka harus dirawat inap.

Berdasarkan penjelasan di atas, perilaku minum obat pada penderita HIV/AIDS merupakan suatu fenomena yang unik dan berbeda antarindividu yang lain dan layak diteliti sehingga peneliti mencoba menggali "Apa makna dari perilaku minum obat yang dijalani penderita HIV/AIDS?" Keunikan ini dapat dilihat dari keputusan bertahan hidup dengan tetap melakukan minum obat, walaupun HIV/AIDS merupakan penyakit kronis yang tidak bisa disembuhkan dan berujung kepada kematian. Fenomena ini mendorong peneliti untuk mencoba menggali pengalaman penderita HIV tentang perilaku minum obat. Untuk menemukan pemahaman yang kaya dalam penelitian, peniliti menggunakan metode kualitatif dengan pendekatan fenomenologis agar mendapatkan pemahaman pengalaman penderita yang lebih kompleks.

\section{METODE}

Metode penelitian yang digunakan adalah metode kualitatif dengan menggunakan pendekatan fenomenologis. Dua orang partisipan bersedia menjadi responden penelitian ini. Adapun karakteristik partisipan dalam penelitian ini adalah:

1. Partisipan didiagnosis dan dinyatakan secara medis terinfeksi HIV.

2. Partisipan tercatat sebagai penderita rawat jalan orang dengan HIV/AIDS di
RSUP Karyadi Semarang yang telah memasuki usia dewasa awal.

3. Partisipan sampai saat ini masih mengikuti terapi obat antiretroviral dan melakukan pemeriksaan berkala di klinik VCT RS. Dr. Karyadi

Metode pengumpulan data yang digunakan adalah wawancara dan observasi terhadap penampilan dan perilaku partisipan. Observasi dalam penelitian ini ditujukan untuk mengenal lingkungan tempat tinggal partisipan.

Hasil wawancara diolah dengan mengikuti alur analisis data fenomenologis. Alur analisis data fenomenologis berawal dari pembacaan transkrip berkali-kali dengan teliti (Creswell, 1997; La Kahija, 2006). Selanjutnya transkrip yang berisi ucapan verbatim ditemukan tema-temanya lewat horisonalisasi di mana seluruh isi transkrip diperlakukan sama. Lewat proses itu, peneliti membiarkan tema-tema muncul. Tema-tema itu kemudian dikelompokkan ke menjadi unit-unit makna yang selanjutnya dideskripsikan secara tekstural dan struktural. Deskripsi tekstural adalah deskripsi yang didasarkan pada ucapan asli partisipan yang menguatkan tema-tema yang ditemukan; sementara deskripsi struktural adalah deskripsi peneliti yang berisi interpretasi atas ucapan partisipan. Pada akhirnya, proses deskripsi itu mengarah pada tema pokok yang menyatukan pengalaman partisipan.

\section{HASIL DAN PEMBAHASAN}

Menerima hasil diagnosis adalah peristiwa psikologis yang mengguncangkan. Ketika mendapatkan hasil diagnosis, partisipan terkejut, takut, bingung, dan terpukul. Perasaan campur-aduk itu secara khusus dirasakan oleh partisipan yang melihat kehidupannya sebagai aktivitas yang lepas dari aktivitas yang rentan tertular HIV. 
Subjek \#1 mengungkapkan perasaannya:

"Hancur..hancur banget..hancur saya mau pingsan di kantoran PT, waktu diberitau. Gimana nih padahal saya gak pernah, suami saya gak pernah pulang..mungkin ini kesalahan. Saya seperti belum percaya. Padahal saya gak pernah keluar rumah. Saya jualan sembako kan di rumah gak pernah keluar. Suntik gak pernah"

Secara lebih ekstrem, partisipan lain menunjukkan keinginan untuk mengakhiri hidup ketika mengetahui hasil diagnosis, seperti yang diungkapkan oleh Subjek \#2 berikut ini:

"Tadinya sih sempat putus asa ya, bukan putus asa lagi kayak gimana ya ...ya sempat nekat juga. Ya Istilahnya pengen mati. Kalau disana, di kampung kan ada obat buat ngeracunin ikan, obat itu ya dimakan aja."

Berbagai perasaan yang berkecamuk itu muncul karena partisipan tidak mengetahui bagaimana mereka tertular oleh penyakit yang secara sosial dianggap sebagi stigma. Keadaan itu diperparah oleh penolakan dari orang-orang terdekat. Partisipan memperlihatkan rasa putus asa dan tidak berdaya menghadapi diagnosis medis. Upaya awal dalam menenangkan diri dijalani lewat jalur religius-spiritual, khususnya lewat doa dan kepasrahan-diri. Kedua partisipan mengungkapkan:

Subjek \#1: "Sholat hajat malam saya kuatkuatkan bagaimana ya caranya saya bisa bangkit kembali... Sholat saya malah tekun. Saat itu saya masih di Jakarta. Sholat saya tekun... tiap kali sholat, minta agar dikasih sehat dan panjang umur. Ya sekarang saya minta itu aja. Soalnya kalo sehat saya bisa apa-apa."

Subjek \#2: “..mungkin ini terlalu berat. Saya hanya bisa menangis menangis... kematian itu mengerikan. Kalo sudah ikhlas, mungkin wis takdire ya bagaimana, mau kata apa."

Selain koping spiritual, dukungan sosial baik berupa dukungan emosional dari orang-orang terdekat maupun berupa pengalaman berbagi dengan sesama penderita HIV telah mendorong dan memantapkan partisipan untuk mencari bantuan medis bagi kesembuhan mereka. Dukungan informasional dan bantuan finansial dari rumah sakit juga memantapkan niat mereka untuk menjalani penanganan medis dengan meminum obat.

Bagi partisipan, AIDS tetap merupakan penyakit yang tidak bisa disembuhkan. Komitmen mereka untuk minum obat muncul bukan karena adanya harapan atau keyakinan untuk sembuh. Obat yang mereka konsumsi membawa efek samping yang berat, seperti yang diungkapkan oleh kedua partisipan berikut ini:

Subjek \#1: "Waktu minum obat pertama tu kan nganu mbak kondisine lemah, gak mau makan, mual-mual. Kadang wis caracarane saya kira saya dah mau mati, jalan saja sini sampai tanggul tu... gak bisa jalan saya. gak bisa."

Subjek \#2: "Karna saya belum transfusi darah, kita mau makan ikan, ini ditaruh ni sakit semua, trus tangan begini kaki begini (partisipan memperagakan) trus mulut saya sampe mlencong gini..ngomong juga pelo, darah tinggi kan gitu juga ...."

Efek samping dari obat ini menyebabkan partisipan mengalami sakit yang cukup parah baik secara psikis maupun fisik. Kondisi ini memunculkan stres baru karena kondisi tubuh mereka yang semakin memburuk dan tidak bisa bekerja untuk memenuhi kebutuhan hidup keluarga. Meski demikian, mereka tetap konsisten meminum obat. Konsistensi itu dikuatkan 
oleh keinginan memiliki durasi hidup yang lebih panjang. Obat dipandang sebagai "penyambung nyawa". Subjek \#1 mengung-kapkan arti obat bagi penyakitnya:

"Sebagai tambah umur, kalo gak ada itu mungkin umur saya enggak panjang, kan nyowone kan sama obat itu. Obat itu nyawa.... Kalo gak ada obat itu kan mungkin udah drop."

Senada dengan itu Subjek \#2 juga mengungkapkan bagaimana obat dapat menjadi jembatan yang bisa membantunya lebih optimistis dalam menjalani kehidupan yang lebih panjang. Rini mengatakan:

"Arti obat bagi saya..inilah adalah kehidupanku ke depan karena saya merasa dengan minum obat saya jadi lebih baik dari sebelumnya."

Konsistensi dalam meminum obat juga dikuatkan oleh harapan partisipan dalam melihat keberhasilan anak-anak mereka di masa depan. Keberhasilan anak dalam mencapai cita-cita hidup adalah harapan mereka yang cukup kuat dalam mengupayakan hidup yang lebih panjang. Menyaksikan keberhasilan anak adalah pendorong yang cukup kuat bagi mereka dalam menjalankan perilaku minum obat, seperti yang menjadi jelas dalam pernyataan kedua partisipan berikut ini:

Subjek \#1: "Pengin hidup lebih lama lagi. Kasian anak-anak, masih kecil masak ditinggal ayah ibunya. Saya kan pengin membahagiakan anak-anak, mewujudkan cita-citanya jadi kenyataan... "Saya ingin hidup saya ingin membahagiakan anak saya. Itu hanya satu kali. Ini kenyataan. gitu."

Subjek \#2: "Sekarang saya ke depannya punya harapan, semoga harapan itu dikabulkan walaupun cuma usaha Sarmier semoga usaha saya lancar... Ya, kita bisa liat anak.ya kita bisa liat anak..biarpun entah kita masih setahun lagi dua tahun lagi..Mudah-mudahan saya diberi kesehatan dan umur yang panjang berkumpul dengan anak-anak dan saya bisa melanjutkan cita-cita anak saya".

Jelas bahwa obat secara fisik diharapkan diharapkan bisa memperlambat keparahan penyakit. Obat memang diakui oleh partisipan sebagai medium yang bisa meringankan beban rasa sakit dan kemunduran fisik mereka meskipun pada awalnya terasa memperparah kondisi fisik dan psikis mereka. Dampak positif dari obat dirasakan secara perlahan-lahan. Keduanya melaporkan pengalaman positif:

Subjek \#1: "Badannya ki caran-carane makin fit gak seperti dulu...

Subjek \#2: "Ada perkembangan merasa lebih baik, kan awalnya dadanya ini kan (mencontohkan kalo nafasnya sesak) begini kan setiap detik, setiap jam setiap waktu terus.. pelanpelan ilang..pelan-pelan ilang. “

Tidak dipungkiri bahwa obat telah membawa dampak positif bagi kondisi fisik mereka. Meski demikian, harapan akan keberhasilan anak adalah penguat psikis yang membantu mereka dalam mengatasi efek samping obat dan konsisten meminum obat. Dalam perspektif ini, perilaku minum obat dilihat sebagai ritual yang membantu realisasi dari harapan mereka bagi anakanak mereka di masa depan.

\section{KESIMPULAN}

Kedua partisipan dalam penelitian ini memperlihatkan makna meminum obat bagi penderita HIV/AIDS. Penderita HIV/AIDS harus mengalami penderitaan fisik dan psikis dari efek samping dari obat yang 
mereka minum. Meski demikian, mereka tetap bisa bertahan dalam meminum obat. Perilaku minum obat adalah ritual yang meringankan penderitaan fisik. Dalam ritual ini, ada kebosanan. Meski demikian, partisipan memiliki harapan untuk melihat keberhasilan anak-anak mereka dalam obat yang minum. Harapan itu menjaga konsistensi mereka dalam meminum obat.

\section{DAFTAR PUSTAKA}

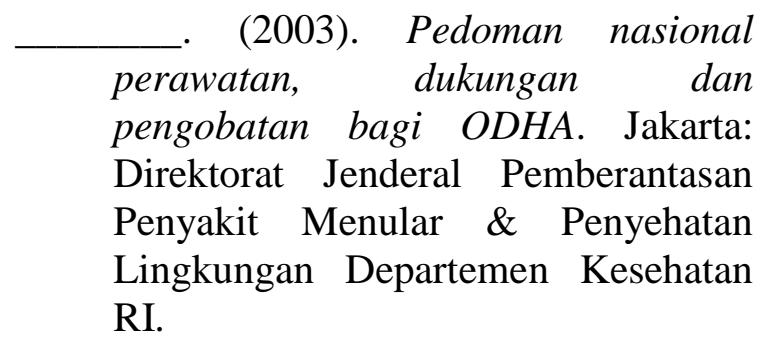

. Apa terapi antiretroviral itu?

(2009, 26 Mei). Diunduh dari

http://www.spiritia.or.id/art/bacaart.p

$\underline{\mathrm{hp}}$ ?artno=1001
Chaplin, J. P. 2000. Kamus lengkap Psikologi. Jakarta : PT Raja Grafindo Persada.

Creswell, J. W. (1997). Qualitative inquiry and research design: Choosing among five approaches. Thousand Oaks. CA: Sage.

La Kahija, Y. F. (2006). Pengenalan dan penyusunan proposal/skripsi penelitian fenomenologis. Semarang : Fakultas Psikologi Universitas Diponegoro

Sanderson, C. A. (2004). Health Psychology. New Jersey: John Willey \& Sons, Inc

Seligson, M. R. \& Peterson, K. E. (1992). AIDS prevention and treatment: Hope, humor, and healing. New York: Hemisphere Publishing Corp. 